\title{
PENGGUNAAN STRATEGI PEMBELAJARAN AKTIF TIPE EVERYONE IS A TEACHER HERE (ETH) PADA POKOK BAHASAN REAKSI OKSIDASI REDUKSI DI KELAS X SMA
}

\author{
Yeva Olensia \\ Universitas Islam Negeri Raden Fatah Palembang \\ Email: olensiay@gmail.com
}

\begin{abstract}
Abstrak: Penelitian ini dilatarbelakangi oleh rendahnya hasil belajar siswa pada pokok bahasan reaksi oksidasi reduksi, hal ini disebabkan karena rendahnya keaktifan siswa selama proses pembelajaran. Salah satu upaya yang dapat dilakukan untuk meningkatkan hasil belajar siswa adalah dengan menggunakan strategi pembelajaran aktif tipe Everyone is A Teacher Here (ETH). Penelitian ini bertujuan untuk mengungkapkan hasil belajar siswa yang menggunakan strategi pembelajaran aktif tipe Everyone is A Teacher Here (ETH) dan pembelajaran konvensional pada pokok bahasan reaksi oksidasi reduksi di kelas X di SMAN 1 Gunung Talang. Jenis penelitian ini adalah eksperimen dengan desain Randomized Control-Group Posttest Only Design. Populasi penelitian ini adalah keseluruhan siswa kelas X semester II SMAN 1 Gunung Talang pada tahun ajaran 2010/2011. Sampel dari penelitian diambil dengan teknik Random Sampling. Sebagai kelas eksperimen adalah kelas SKU dan kelas kontrol adalah kelas SSN4. Hasil belajar yang diungkapkan pada penelitian ini berupa hasil belajar ranah kognitif. Uji hipotesis digunakan dengan menggunakan uji-t, karena sampel terdistribusi normal dan homogen. Dari hasil penelitian diperoleh bahwa rata-rata hasil belajar siswa dengan menggunakan strategi pembelajaran aktif tipe Everyone is A Teacher Here (ETH) lebih tinggi secara signifikan dari hasil belajar siswa dengan menggunakan metode konvensional. Setelah dilakukan uji-t pada taraf signifikan 0.05 diperoleh $\mathrm{t}_{\text {hitung }}=4.51$ dan $\mathrm{t}_{\text {tabel }}=1.99\left(\mathrm{t}_{\text {hitung }}>\mathrm{t}_{\text {tabel }}\right)$ berarti hipotesis diterima. Sehingga dapat disimpulkan bahwa hasil belajar siswa yang belajar dengan strategi pembelajaran aktif tipe Everyone is $A$ Teacher Here (ETH) lebih tinggi secara signifikan dari hasil belajar siswa yang belajar dengan pembelajaran konvensional pada pokok bahasan reaksi oksidasi reduksi di kelas X SMAN 1 Gunung Talang.
\end{abstract}

Kata kunci: ETH, hasil belajar, reaksi oksidasi reduksi, strategi pembelajaran aktif

\section{PENDAHULUAN}

Dalam Kurikulum Tingkat Satuan Pendidikan (KTSP), proses pembelajaran menuntut keaktifan siswa. Siswa tidak hanya menerima materi dari guru saja. Guru bertindak sebagai fasilitator, dimana pada kegiatan di dalam kelas, para siswa bukan lagi objek, namun subjek, sehingga proses pembelajaran lebih efektif. Kegiatan-kegiatan yang terpusat pada peserta didik (student center activities) merupakan iklim yang dapat membangkitkan semangat belajar (Mulyasa, 2007: 154).

Strategi pembelajaran yang tepat hendaknya dilaksanakan pada setiap jenjang pendidikan serta dalam semua mata pelajaran termasuk kimia. Kimia merupakan salah satu ilmu yang mempunyai peranan penting dalam upaya penguasaan ilmu pengetahuan dan teknologi. Hasil belajar kimia merupakan indikator keberhasilan proses kegiatan pembelajaran kimia. Semakin tinggi hasil belajar maka akan semakin tinggi pula tingkat keberhasilan pembelajaran. Namun kenyataan di lapangan menunjukkan hasil belajar kimia yang dicapai siswa masih rendah. Berdasarkan pemantauan dan diskusi dengan guru kimia kelas X SMAN 1 Gunung Talang yang dilakukan melalui kunjungan ke sekolah terungkap bahwa rendahnya hasil belajar kimia siswa kelas X. Rendahnya hasil belajar siswa dapat 
dilihat dari persentase ketuntasan hasil belajar kimia siswa pada ulangan harian reaksi oksidasi reduksi kelas X pada tahun ajaran 2009/2010. Dari delapan kelas yang ada, kelas SBI1 persentase ketuntasannya $=50 \%$, kelas SBI2 $=21.87 \%$, kelas SKU $=50 \%$, kelas SSN1 $=64.51 \%$, kelas $\mathrm{SSN} 2=55.17 \%$, kelas SSN3 $=$ $71.42 \%$, kelas SSN4 $=97.14 \%$ dan kelas SSN5 $=64.7 \%$. Berdasarkan persentase ketuntasan hasil belajar siswa tersebut dapat diketahui bahwa masih banyak siswa yang nilainya tidak mencapai KKM (70).

Rendahnya hasil belajar siswa tersebut karena rendahnya aktivitas siswa dalam proses pembelajaran. Rendahnya aktivitas siswa dapat dilihat dari sedikitnya siswa yang mengemukakan pendapat dan menjawab pertanyaan yang berdampak pada kemampuan siswa dalam berinteraksi pada proses pembelajaran. Rendahnya keaktifan siswa disebabkan karena belum adanya penggunaan strategi pembelajaran yang tepat. Dalam pembelajaran, guru menggunakan metoda ceramah sehingga kegiatan pembelajaran hanya berpusat pada guru, sebagian besar siswanya menjadi pasif dan tidak terlibat secara aktif.

Strategi pembelajaran aktif tipe Everyone is A Teacher Here (ETH) digunakan dalam pokok bahasan reaksi oksidasi reduksi karena pada materi ini hasil belajar siswa masih rendah. Selain itu, materi dalam pokok bahasan ini memuat konsep, pengetahuan serta perhitungan yang membutuhkan tingkat pemahaman yang tinggi, sehingga harus dipahami siswa secara mendalam. Konsep-konsep itu akan lebih mudah dipahami dan diingat oleh siswa apabila mereka mampu menemukan sendiri dan menyampaikan kembali pemahamannya kepada siswa lainnya secara komunikatif. Siswa akan lebih termotivasi dalam proses pembelajaran jika mereka diikutsertakan secara aktif dalam pembelajaran dan tidak hanya menerima materi dari guru. Pernyataan ini juga didukung oleh pendapat Suryosubroto (1997: 71) "Guru dalam menyajikan bahan pelajaran harus mengikutsertakan siswanya secara aktif baik individual maupun kelompok".

Strategi pembelajaran aktif tipe Everyone is A Teacher Here (ETH) memungkinkan siswa untuk berdiskusi dalam kelompok yang membantu siswa untuk menemukan pemahaman tentang materi yang dipelajari dan bisa menjelaskan pemahamanya kepada anggota kelompok dan siswa lainnya di kelas. Diskusi kelompok dalam strategi ini dapat membantu siswa yang belum paham dengan mendapat penjelasan dari anggota kelompok yang sudah paham. Dengan adanya diskusi kelompok dan diskusi kelas dalam pembelajaran dengan strategi ETH menandakan adanya interaksi antara siswa dengan siswa, siswa dengan guru dan siswa dengan sumber belajar sehingga nantinya diharapkan aktivitas dan hasil belajar siswa meningkat.

Penggunaan strategi ini telah diteliti sebelumnya oleh Rozalina (2009) pada pokok bahasan konsep tata surya dan konsep suhu kalor. Dari hasil penelitian yang telah dilakukan, disimpulkan bahwa metoda pembelajaran aktif tipe ETH dapat meningkatkan hasil belajar siswa pada pokok bahasan konsep tata surya dan konsep suhu kalor. Selain itu, dari hasil penelitian yang telah dilakukan Nofidri Yenti (2010) pada pokok bahasan minyak bumi dengan menggunakan model belajar aktif tipe ETH lebih tinggi bila dibandingkan dengan hasil belajar siswa dengan menggunakan metoda konvensional. Berdasarkan latar belakang 
diatas penulis tertarik melakukan penelitian dengan judul "Penggunaan Strategi Pembelajaran Aktif Tipe Everyone Is A Teacher Here (ETH) Pada Pokok Bahasan Reaksi Oksidasi Reduksi di Kelas X SMA/MA”.

\section{METODE PENELITIAN}

\section{Jenis dan Desain Penelitian}

Penelitian ini merupakan penelitian eksperimen dengan desain "Randomized Control Group-Posttest Only Design”. Bentuk rancangan penelitian disajikan dalam tabel 1.

Tabel 1. Bentuk Rancangan Penelitian

\begin{tabular}{lll}
\hline Kelas & Perlakuan & Tes \\
\hline Eksperimen & $\mathrm{X}$ & $\mathrm{T}$ \\
Kontrol & - & $\mathrm{T}$ \\
\hline
\end{tabular}

\section{Subjek Penelitian}

Populasi dalam penelitian ini adalah keseluruhan siswa kelas X semester II SMAN 1 Gunung Talang pada tahun ajaran 2010/2011. Sampel diambil dengan teknik random sampling dan didapat dua kelas sampel yaitu kelas SKU sebagai kelas eksperimen dan kelas SSN4 sebagai kelas kontrol.

\section{Prosedur Penelitian}

1. Tahap persiapan

a. Menentukan jadwal kegiatan penelitian.

b. Menyusun materi pembelajaran.

c. Mempersiapkan Rencana Pelaksanaan Pembelajaran (RPP) untuk materi reaksi oksidasi reduksi.

d. Menentapkan sampel penelitian.

e. Mempersiapkan perangkat pembelajaran berupa bahan ajar dan kartu indeks.

2. Pembelajaran pada kedua kelas sampel berdasarkan kurikulum KTSP.

Perlakuan yang dilakukan pada kedua kelas sampel disajikan dalam tabel 2.

Tabel 2. Perlakuan yang dilakukan pada kedua kelas sampel

\begin{tabular}{|c|c|c|}
\hline No & Kelas eksperimen & Kelas kontrol \\
\hline 1 & $\begin{array}{l}\text { Kegiatan pendahuluan } \\
\text { a. Guru memeriksa kesiapan siswa untuk } \\
\text { mengikuti proses pembelajaran. } \\
\text { b. Guru memberikan apersepsi kepada } \\
\text { siswa. } \\
\text { c. Guru memberikan motivasi kepada } \\
\text { siswa. } \\
\text { d. Guru menjelaskan tujuan pembelajaran } \\
\text { dan kompetensi dasar yang akan dicapai. } \\
\text { e. Guru menyampaikan cakupan materi } \\
\text { reaksi oksidasi reduksi dan penjelasan } \\
\text { uraian kegiatan sesuai dengan silabus } \\
\text { secara singkat. }\end{array}$ & $\begin{array}{l}\text { Kegiatan pendahuluan } \\
\text { a. Guru memeriksa kesiapan siswa untuk } \\
\text { mengikuti proses pembelajaran. } \\
\text { b. Guru memberikan apersepsi kepada } \\
\text { siswa. } \\
\text { c. Guru memberikan motivasi kepada } \\
\text { siswa. } \\
\text { d. Guru menjelaskan tujuan pembelajaran } \\
\text { dan kompetensi dasar yang akan dicapai. } \\
\text { e. Guru menyampaikan cakupan materi } \\
\text { reaksi oksidasi reduksi dan penjelasan } \\
\text { uraian kegiatan sesuai dengan silabus } \\
\text { secara singkat. }\end{array}$ \\
\hline
\end{tabular}




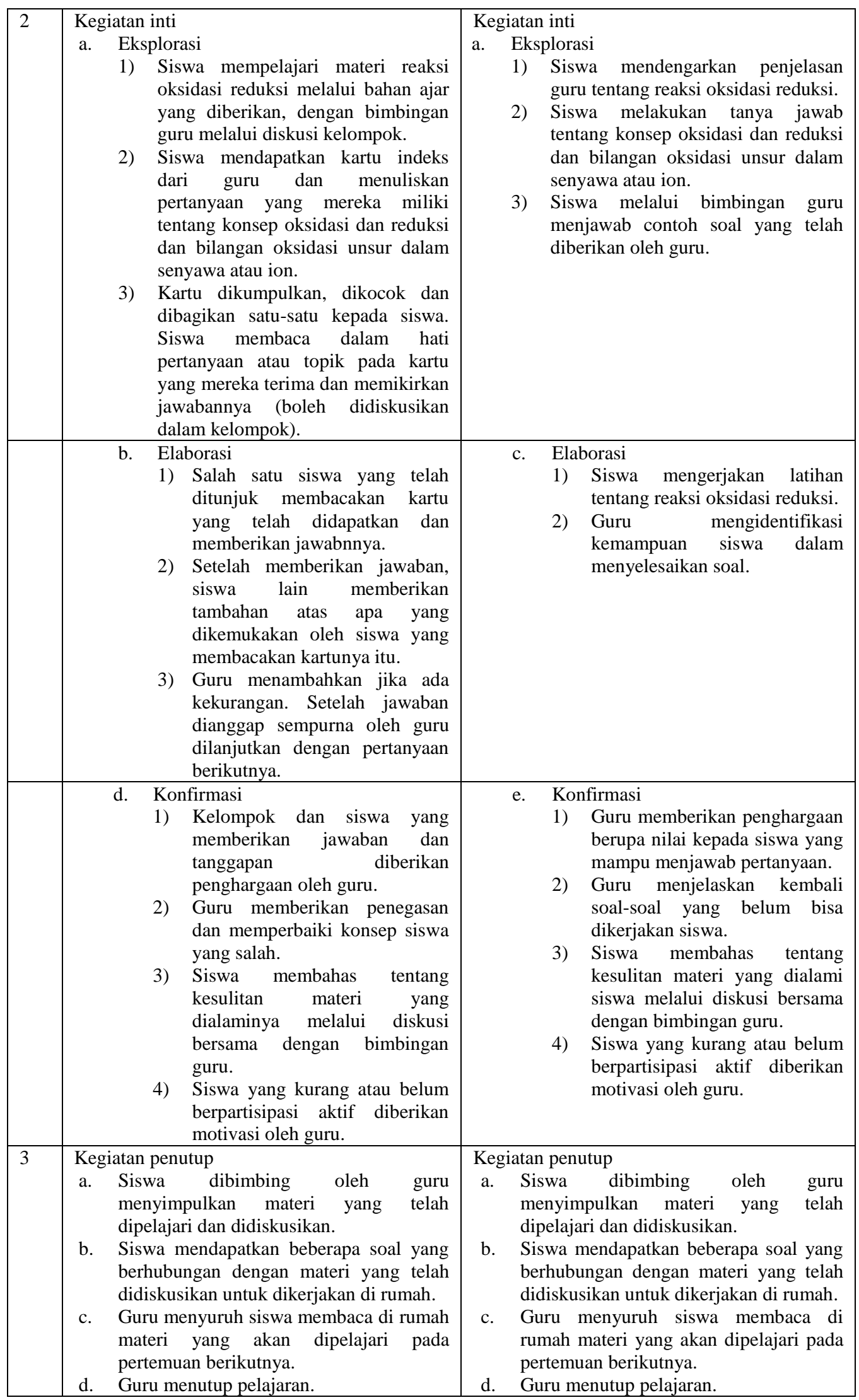


3. Tahap penyelesaian

a. Mengolah data yang didapat pada kelas kontrol dan kelas eksperimen.

b. Menarik kesimpulan dari hasil yang didapat sesuai dengan teknik analisis data.

\section{Teknik dan Instrumen Pengumpul Data}

Instrumen pengumpul data dalam penelitian ini adalah tes hasil belajar berupa tes objektif untuk mengukur hasil belajar kognitif dengan lima pilihan jawaban. Tes yang diujikan sesuai dengan materi yang diberikan selama proses belajar mengajar berlangsung. Tes dilakukan setelah pembelajaran pokok bahasan reaksi oksidasi reduksi selesai dipelajari. Tes akhir berfungsi untuk melihat hasil belajar kimia siswa setelah diberi perlakuan dengan strategi ETH di kelas eksperimen dan pembelajaran konvesional di kelas kontrol. Sebelumnya dilakukan uji validitas (isi dan item), reliabilitas tes, indeks kesukaran dan daya beda.

Untuk menganalisis data hasil penelitian, terlebih dahulu diadakan uji normalitas dan uji homogenitas untuk menentukan sampel terdistribusi normal atau tidak dan memiliki varians yang homogen atau tidak. Setelah itu baru dilakukan uji hipotesis.

\section{HASIL DAN PEMBAHASAN}

Nilai hasil belajar siswa kelas eksperimen yaitu 72.18 dan kelas kontrol yaitu 56.40. Hasil ini menunjukkan bahwa nilai hasil belajar kelas eksperimen dengan menggunakan strategi pembelajaran aktif tipe Everyone is A Teacher Here (ETH) lebih tinggi secara signifikan dibandingkan dengan kelas kontrol dengan pembelajaran konvensional.

Kedua kelas terdistribusi normal dan homogen, sehingga untuk menguji hipotesis digunkan uji-t, dimana dari analisis diperoleh $t_{\text {hitung }}=4.51>t_{\text {tabel }}=1$.99. Hal ini menunjukkan hipotesis kerja (Hi) diterima dan dapat disimpulkan bahwa hasil belajar siswa yang belajar dengan strategi pembelajaran aktif tipe Everyone is $A$ Teacher Here (ETH) lebih tinggi secara signifikan dibandingkan dengan kelas kontrol dengan pembelajaran konvensional pada pokok bahasan reaksi oksidasi reduksi di SMAN 1 Gunung Talang.

Lebih tingginya hasil belajar kimia siswa di kelas eksperimen dengan menggunakan strategi pembelajaran aktif tipe Everyone is A Teacher Here (ETH) disebabkan karena dengan menggunakan strategi ini siswa berdiskusi dalam kelompok. Siswa dapat saling berbagi pengetahuan antar siswa yang sudah memahami materi dengan siswa yang masih belum paham. Siswa juga aktif berdiskusi dalam membuat pertanyaan dan mendiskusikan jawabannya. Interaksi antar siswa dalam pembelajaran dapat berjalan dengan baik. Dengan meningkatnya interaksi siswa menandakan pembelajaran sudah terpusat pada peserta didik sehingga akan meningkatkan semangatnya dalam belajar. Pembelajaran yang terpusat pada peserta didik akan lebih meningkatkan semangat belajar (Mulyasa, 2007: 154).

Pada strategi pembelajaran aktif tipe Everyone is A Teacher Here (ETH) siswa dituntut untuk dapat menerangkan materi yang sudah dipahaminya. Bagi siswa yang belum memahami materi, maka dituntut untuk bertanya pada anggota kelompoknya yang sudah paham, sehingga siswa saling berbagi mengenai 
informasi yang didapatnya melalui diskusi dengan anggota kelompok. Strategi ini memberi kesempatan bagi setiap siswa untuk bertindak sebagai "guru" bagi siswa lain (Silberman, 2006: 183).

Dalam proses pembelajaran dengan strategi ETH setiap siswa di kelas mendengarkan penjelasan dari temannya. Sehingga setiap siswa bisa memberi tanggapan atas jawabannya tersebut. Dengan menggunakan strategi ETH ini siswa bisa membagi pengetahuan yang diperoleh pada teman yang lain. Setiap siswa disini juga bertanggung jawab dalam membuat pertanyaan sehingga siswa lebih aktif berfikir untuk mengembangkan ide dan pemahamannya tentang materi yang dipelajari. Disini siswa juga dilatih berani mengemukakan pendapat dan bisa menghargai pendapat orang lain. Strategi ini mudah untuk mendapatkan partisipasi seluruh kelas dan pertanggungjawaban individu (Silberman, 2006: 183).

Dengan strategi ETH siswa bisa menjelaskan pemahamannya kepada siswa lain yang belum paham. Siswa disini tidak hanya mendengar penjelasan dari guru saja, tetapi juga mendiskusikan materi pelajaran yang dipelajari dalam kelompok dan anggota kelas lain sehingga akan lebih meningkatkan pemahaman siswa terhadap materi pelajaran. Ini sesuai dengan yang dikatakan oleh Silberman (2006: 23), "yang saya dengar saya lupa, yang saya lihat saya sedikit ingat, yang saya diskusikan saya sedikit pahami, yang saya ajarkan pada orang lain saya kuasai".

Sedangkan pada kelas kontrol yang menggunakan pembelajaran konvensional hasil belajarnya lebih rendah hal ini disebabkan karena pada kelas ini siswa kurang atif. Siswa lebih pasif dan cenderung untuk mendengar penjelasan dari guru saja, sehingga motivasi siswa untuk belajar lebih rendah dan cenderung membuat siswa menjadi jenuh. Hanya sedikit siswa yang menjawab pertanyaan dari guru dan memberi tanggapan. Guru lebih banyak berbicara dan interaksi antara guru dengan siswa dan interaksi antara siswa dengan siswa sangat sedikit. Hal ini sesuai dengan pendapat Nasution (2008: 209) yang mengatakan bahwa "dalam pembelajaran dengan metode konvensional siswa kebanyakan bersikap pasif mendengarkan uraian".

\section{KESIMPULAN DAN SARAN}

Hasil belajar siswa pada pokok bahasan reaksi oksidasi reduksi dengan menggunakan strategi pembelajaran aktif tipe Everyone is A Teacher Here (ETH) lebih tinggi secara signifikan dari hasil belajar siswa dengan menggunakan pembelajaran konvensional.

Diharapkan guru kimia dapat menerapkan strategi pembelajaran aktif tipe Everyone is A Teacher Here (ETH) pada pokok bahasan reaksi oksidasi reduksi. Selain itu diharapkan juga pada peneliti selanjutnya untuk dapat menerapkan strategi pembelajaran aktif tipe Everyone is A Teacher Here (ETH) pada pokok bahasan lain yang sesuai. Kendala yang dihadapi pada saat pelaksanaan strategi ini adalah tidak semua pertanyaan dapat dibahas dan banyak pertanyaan dari siswa yang sama. Maka pada penerapan strategi ini diharapkan pertanyaan yang dibahas yang belum diketahui jawabannya oleh siswa dalam kelompok dan dalam membuat pertanyaan hendaknya dibedakan indikator pada tiap kelompok. 


\section{DAFTAR RUJUKAN}

Arikunto, S. (2008). Dasar-Dasar Evaluasi Pendidikan. Jakarta: Bumi Aksara

Mulyasa. (2007). Kurikulum Tingkat Satuan Pendidikan. Bandung: PT. Remaja Rosdakarya.

Nasution. (2008). Berbagai Pendekatan Dalam Proses Belajar dan Mengajar. Jakarta: Bumi Aksara.

Nofidri, Yenti (2010). Pengaruh Model Pembelajaran Aktif Tipe Everyone is A Teacher Here Terhadap Hasil Belajar Siswa Pada Pokok Bahasan Minyak Bumi Kelas X di SMAN 1 Pariangan. Padang: UNP.

Rozalina. (2009). Pengaruh Metoda Belajar Aktif Tipe Everyone is A Teacher Here (ETH) Terhadap Hasil Belajar Siswa Pada Pokok Bahasan Konsep Tata Surya dan Konsep Suhu Kalor di Kelas X SMAN 5 Padang. Padang: UNP

Silberman, Melvin. (2006). Active Learning 101 Cara Belajar Aktif. Bandung: Nusa Media

Suryosubroto. (1997). Proses Belajar Mengajar di Sekolah. Jakarta: PT. Rineka Cipta. 